\title{
Gaining Competitiveness in the Global Business World through the Implementation of International Human Resource Management
}

\author{
Eko Budi Harjo \\ Henley Business School, University of Reading, \\ Reading, United Kingdom
}

\begin{abstract}
Telkom's vision to become a dominant telecommunication player in the region brings Telkom to expand its businesses internationally. The effectiveness of human resource management policies and practices across national boundaries has become a key strategy for Telkom to achieve competitive advantage in the global markets. As a Multinational Company, Telkom should be concerned about the employment practices and systems used in international affiliates for hostcountry nationals. The development of comprehensive IHRM policies and practices may enable firms to be more proactive in their approach to internationalization and to have a greater choice over the types of markets and countries they enter.

This paper is a study on International Human Resource Management from both empirical studies by scholars and practices that have been implemented by some multinational companies as their best practices. A theoretical framework will be elaborated to provide some basic knowledge about this field. It analyzes some emerging issues and best practices of some multinational companies in their implementation of international human resource management. This paper also analyzes on how Telkom implements International Human Resource Management especially in the context of regionalization strategy on its international expansion program (INEX). Some HR key practices for gaining competitive advantage will be discussed. It is limited on three important HR practices: recruiting global employee, training and development, and re-entry policy.

Based on the studies, best practices, and current analysis on Telkom's practices, some recommendations are developed to improve the company's practices on international HRM in order to gain global competitiveness as a key factor in winning global competition.
\end{abstract}

Keywords: Global Business; International HRM; Global Competitiveness

\section{A. Background}

\section{INTRODUCTION}

The telecommunication industry in Indonesia has unique characteristics compared to other countries, such as a very stiff competition, a price war, and the fact that about 30 percent of Indonesian subscribers own more than one SIM card. The competition is very intense because there are 10 telecommunication operators which serve up to 245.2 million people in Indonesia. Being a dominant player, Telkom actions shape the Indonesian telecommunication industry and are usually followed by other operators.
Telkom has the goal of becoming a leading TIMES (Telecommunication, Information, Media, Edutainment and Services) player in the region and has an obligation, as a stateowned company, to contribute to the economic and social development of the nation. To achieve such a goal and to meet such an obligation, Telkom has set up several strategic initiatives including one of the top initiatives, which is to become a center of excellence that focuses on human capital development and involvement. This initiative will deeply rely on how the company defines its HR policy and how it is implemented.

Telkomôs vision to become the dominant telecommunication player in the region has caused Telkom to expand its businesses internationally. Since 2010, Telkom has expanded its overseas business from one country, which is Singapore, to six countries in 2013 and is expected to grow to over 10 countries including Australia and several countries in the Asia-Pacific region in 2015. The effectiveness of human resource management policies and practices across national boundaries has become a key strategy for Telkom in its attempt to achieve a competitive advantage in the global markets. As a Multinational Company, Telkom should be concerned about the employment practices and systems used in international affiliates for host-country nationals [1]. The development of comprehensive IHRM policies and practices may enable firms to be more proactive in their approach to internationalization and to have a greater choice over the types of markets and countries they enter [2].

\section{B. Globalization}

In a situation where technology is rapidly developing, globalization in all aspects is increasingly becoming a reality. Information and telecommunications technology have narrowed the distance between countries, and sometimes the situation appears to be borderless. People in one particular country can easily find out what is happening in other countries through media such as the Internet, international TV broadcasts, Facebook, Twitter and direct communication by telephone call or internet phone. People in one country consume products that produced in another country. Free trade areas in specific regions are becoming a trend, because there is a need for collaboration among countries in those regions. They need collaboration to maximize resources, such as natural resources, energy resources, and human resources. Moreover, they need new markets in other countries. 
Furthermore, the ASEAN Economic Community (AEC) will soon be implemented at the end of 2015, and it will provide all ASEAN countries both the right to do business freely and the obligation to open their markets to other countries. It means that the readiness of companies to exploit business opportunities has become a key factor. In turn, the readiness of its human resource management that suits managing employees in different countries become more important.

Briscue, Schuler and Claus [3] argued that there are many factors that drive the interest and need to globalize ñincreased travel, rapid and extensive global communication, rapid development and transfer of new technology, free trade, education, migration of large numbers of people, knowledge sharing, pressure on costs, search for new markets, homogenization of cultures, and e-commerceò. Some of those specific factors i.e. ñrapid and extensive global communication, free trade, migration of large numbers of people, and search for new marketsò has become the drivers for Telkom to expand its business globally.

A company that has expanded its business globally needs to implement HR or employment policies and practices that are suitable for the host-country nationals. The effectiveness of human resource management policies and practices across national boundaries has become a key strategy to achieve a competitive advantage in the global markets. A multinational company should be concerned about the employment practices and systems used in international affiliates for host-country nationals [1]. The development of comprehensive IHRM policies and practices may enable firms to be more proactive in their approach to internationalisation and to have a greater choice over the types of markets and countries they enter [2].

Managing its human resource is very important for a company if it is to beat all of its competitors. This situation becomes more complex when a company, for various reasons, has decided to expand its business internationally.

Recently, more and more companies have begun to operate in foreign markets and compete with both local and global players. Traditional human resources management practices, to some extent, will not be suitable for running a global business that deals with employees with different nationalities.

\section{Internationalization Stages}

MNCs have different stages on their internationalization stages. Bartlett and Ghoshalố [4] distinguish four types of MNCs: multidomestic, international, global, and transnational. Extending on this typology, there are eight forms of internationalization process which are ñinternationalization throught export, international division or global product division, multi-country/multi-domestic strategy, regionalization, the global firm, the transnational firm, the born-global firm, and the globally integrated enterpriseò [5].

Based on an empirical study, Harzing and Ruysseveldt [6] presented three ideal-types of Multinational Company which are assessed by typology elements of ñorganizational design, Interdependence, Local responsiveness, and Control mechanismò First is Global companies, which operate an industry with rather standardized consumer needs that make the realization of economic scale very important. The next is Multidomestic companies that completely reverse of global company. Product or services are differentiated to meet differing local demands, and policies are differentiated to conform to differing governmental and market demands. The last is Transnational companies which combine the characteristics of both global and multidmestic companies. This type of MNCs needs to respond to conflicting strategic needs of global efficiency and national responsiveness. Harzing and Ruysseveldt [6] also underlined the importance of the transfer of knowledge for these companies.

\section{THEORETICAL FRAMEWORK}

\section{A. Global Competitiveness and IHRM}

In order to maintain their sustainability in the global market, firms need to develop a competitive advantage. Over the past few decades, competitive advantage has mostly been related to innovation in technology, branding, business processes, natural resources, and others non-human things. Companies are pursuing competitive strategies aimed at cost reduction, quality improvement, and innovation to gain competitive advantage and beat the competition $\ddot{i}$ both domestically and internationally [7]. They also argued that the effectiveness of firms in designing a competitive strategy can be increased by systematically melding human resource practices with the selected competitive strategy.

\section{B. IHRM Studies Development}

There is a growing literature on the area of international human resource management [2]. Human resource management as an international discipline is an emerging area of academic study, the development of which is presently lacking in the integration of theory and practice [8]. There is evidence, however, that North American and Western European dominate the IHRM literature [9]. The body of knowledge on IHRM has grown significantly as can be seen in Figure 1, as a result of research by scholars and practitioners which has been stimulated by the rapid growth in international business activity [10]. Although it can be classified separately, they are not mutually exclusive but rather as complementary. 


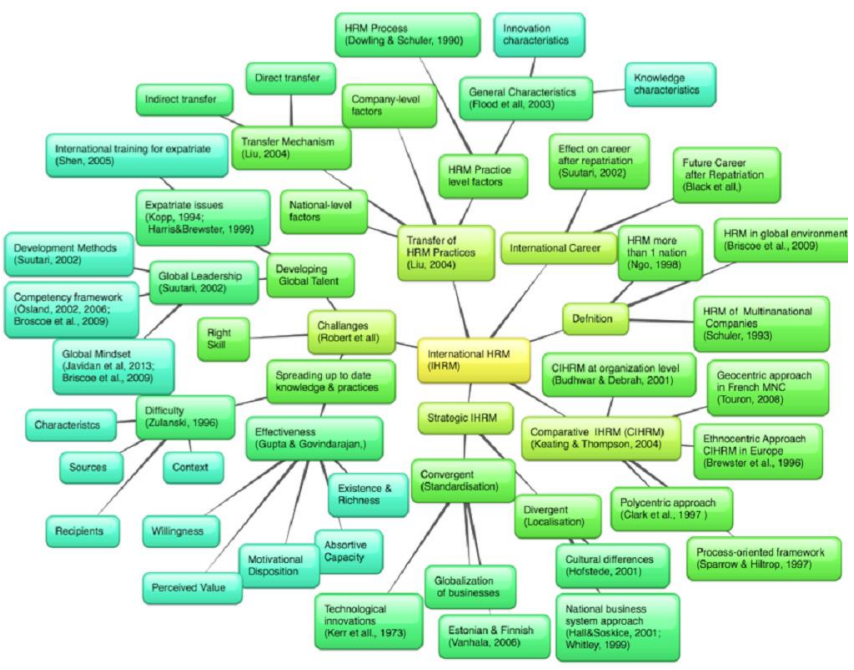

Fig. 1. Mapping of Study in IHRM by Researcher

IHRM is the term used to refer to the instance where an organizationôs human resource management (HRM) entails managing employees in more than one nation [11]. Michael Armstrong [12] defined IHRM as ñthe process of employing, developing and rewarding people in international or global organizations. It involves the worldwide management of people, not just the management of expatriatesò. A broader definition is used by Schuler and his colleagues who defined strategic IHRM as ñhuman resource management issues, functions, policies and practices that result from the strategic activities of multinational enterprises and that impact on the international concerns and goals of those enterprisesò [13].

IHRM is concerned with the way in which organizations that operate across national borders manage their employees, and increasingly the term is applied to all their employees and not just those who are working internationally [14]. Dickmann and his colleagues argued that International HRM (IHRM) has to examine the way in which international organizations manage their human resources in different national contexts [15]. Recently, Briscoe et al. [5] defined the field of IHRM as the study and application of all human resource management activities as they impact the process of managing human resources in enterprises in the global environment.

\section{Issues in IHRM}

Discussion about IHRM covers a wide range of topics, De Cieri and Dowling [16] identified three broad strands in the field of IHRM: (1) HRM in MNCs, which focus on the HR management in international companies, (2) Cross-cultural management (CCM), which deals with the impact of cultural differences on management practices, and (3) Comparative human resource management, which compares HRM systems and practice at both organizational and national levels. Very similar to previous research, Morley and Collins [17] pinpointed three key research themes in IHRM. The first is the debate concerning the extent to which MNCsô ñforeign affiliates (or subsidiaries) act and behave as local firms versus the extent to which their practices resemble those of the parent corporation or some other global standardò. The second is the extent to which management practices are converging or diverging across nation states. The last is the increasing interest in international and comparative studies of HRM in a broadening range of countries.

\section{IHRM ISSUES}

\section{A. IHRM Approach (Standardization vs. Localization)}

One of the basic frameworks in the HRM approach applied by MNCs was introduced by Doz, Bartlett and Prahalad [18] in an article entitled ñGlobal competitive pressures versus host country demands: managing tension in multinational corporationsò. Global competitive pressures mean that company needs to coordinate its operations, both at the headquarters of its country of origin and in its overseas subsidiaries, to fully reaping the benefits of scale and scope. On the other hand, MNC is composed of a set of functions, divisions, or organizational units that operate in their respective local environments and must be sufficiently differentiated to respond to the demands of these local areas. Furthermore, Doz and Prahalad [19] argued that responding to a variety of national demands while maintaining a clear and consistent strategy was the single biggest problem facing MNCs. Bartlett and Ghoshal [20] identified the need for organizations to maintain a ñdynamic balanceò between globalization (implementing globally standard practices) and localization (adapting practices to account for the host environment) if they are to become truly trans-national.

In recent years, a body of research evidence has attempted to illuminate this debate. One critical choice faced by IHRM practitioners is whether and when an organization should adapt its human resource policies and practices to the local context (localization) or maintains the parent companyôs approach (globalization) [21]. Indeed, regarding the issue of balancing the need for global integration and local adoption, Chung, Bozkurt, \& Sparrow [22] provide evidence on the need for balance between localization and globalization, based on their research on two Korean MNCố which had been transforming their HR function from a multi-domestic state to a transnational state where they can be more globally integrated and simultaneously, more locally responsive.

The global integration-local responsiveness framework has also been used in the study of European MNCs. Particularly important is the extensive database of HR practices gathered since the late 1980s by the Cranfield network on European human resource management-CRANET[23]. IHRM policies and practices are influenced by the companyôs structure and strategy [11] and its institutional and cultural environments [24]. There are two main elements that influence how MNCs manage globalization and localization issues, which are extraorganizational and intra-organizational factors. Extraorganizational factors are related with the cultural and institutional framework [25] and [26]. On the other hand, Chung and his colleagues highlight the significance of the role of intra-organizational factors: i.e. actor-related factors, relational factors, and procedural factors [22].

\section{B. IHRM Comparative Study}

Another concern in IHRM studies is comparative HRM (CHRM) that involves the comparison of HR systems and 
practices across nations and regions around the world [10]. Telkom has experienced this issue since it expanded its business to many different countries. Comparative human resource management is about understanding and explaining what differences exist between countries in the way that human resources are managed [27]. Some approaches that were used include the ethnocentric approach [28], the geocentric approach [29], the polycentric approach [30], and the process-oriented framework [31].

Despite the limitations of survey methods and methodological constraints, the Cranet networkôs survey has provided large-scale empirical data since 1990 [32]. They have contributed significantly both to the description and understanding of developments in HRM practice in a constantly increasing number of countries and to the theoretical developments in CHRM. Most studies in CHRM were conducted to explore IHRM in Europe. Hence, there is lack of studies in other regions such as Asia, Australia, and Africa.

\section{GAINING GLOBAL COMPETITIVENESS THROUGH INTERNATIONAL HR PRACTICES}

\section{A. Recruiting and Sourcing Global Employee}

Recruitment is a vital function of human recourse management, which can be defined as the process of searching the right talent and stimulating the employees to apply for jobs in the organization. There are two sources in which a company can get employees who are globally ready: external recruitment or develop internally. Some companies prefer to develop their employees by providing necessary trainings and then assign them with international assignments in their overseas subsidiary. Other companies choose to recruit from external areas, whether from professional labor market or hijack employees from their competitors. Alternatively, recruiting can also be conducted by global employment agencies, commercial recruitment agencies, or specialized consultancies.

Sourcing is the use of one or more strategies to relate talent to organizational vacancies. It may use different sorts of advertisements, using appropriate media, such as newspapers, specialized recruitment media, window advertisements, job centers, job fair, or the Internet. There is a growing trend in using the internet as a sourcing method [33]. The online recruitment market size is estimated to be US $\$$ billion globally [14]. Social networking sites, such as Facebook and Twitter, allow individuals to post and share personal information, which has led many US employers to use social networking sites to screen job applicants [34]. As an IT based company, Telkom should be more familiar with this kind of recruitment tools, especially for Assessment Center unit.

Next issue on choosing employee for international subsidiaries is whether they are from local nationals or expatriates (nationals of the parent company or third-country nationals). Armstrong argue that there are some advantages of employing local nations such as familiar with local markets and community, speak the local language, and can contribute for a long period [12]. Thus, for a long term business operation, local nationals will play important roles in the success of overseas subsidiary. However, expatriates will be required if there is lack of experience and expertise of local nationals. When a company needs to enter the market immediately, they may use expatriates instead of local nationals. For example, when starting to open new business in overseas, TELKOM, mostly used expatriates from home country (Indonesia) instead of employing local nationals.

\section{B. Training and Development}

Training and development plays important role since human resource is one of the most critical source of competitive advantage. Well skilled global employees will determine the success of a company, especially one that operates in global business. Once a company expanded business internationally, there will be a greater challenge for its Training and Development function because it involves multiple subsidiaries and partnership in other countries, developing global strategy, and assignment number of employees to international positions. It has to deal with local culture, local language, local laws and other local contents.

Tarique and Calligiri (1995) in [12] proposed that the following steps should be taken to design a training program for expatriates and local nationals:

- Identify the type of global assignment, e.g. technical, functional, tactical, developmental or strategic/executive.

- Conduct a cross-cultural training needs analysis covering organizational analysis and requirements, assignment analysis of key tasks and individual analysis of skills.

- Establish training goals and measures.

- Develop the program $\ddot{i}$ the content should cover both general and specific cultural orientation; a variety of methods should be used.

- Evaluate training given.

Another issue in MNCôs training and development is how to develop global leaders, since leaders will translate companyố mission into actions, take decision in critical condition, and energize people to achieve highest performance. One aspect that differentiates global leadership development with traditional leadership development is the development of a global mindset, the ability to influence individuals, groups, organizations, and systems that are unlike the leaderôs [35]. This global perspective includes sensitivity to multiple cultures and their differences, work experience in more than one country, and knowledge about how and willingness to seek customers, financial resources and supplies, technology, innovations, and employees throughout the world [12]. For example, to develop its global leader, TELKOM uses Thunderbird Global Mindset Inventory that consists of Intellectual Capital, Psychological Capital, and Social Capital.

Cerdin and Brewster argued that talent management and expatriation are two significantly overlapping but separate areas of research and that bringing the two together has significant and useful implications for both research and practice [36]. They provide framework of global talent management as a combination of high-potential development and global careers development as explained in Figure 2. The concept of global talent management captures the combination 
of the talent segmentation approach of talent management and the broader human resource management policies that contribute to the management of all talented employees. Global talent management is centered on the development of employees, and it includes both high-potentials development and global careers development. Global career development policies should be developed and integrated with Telkom global leadership development.

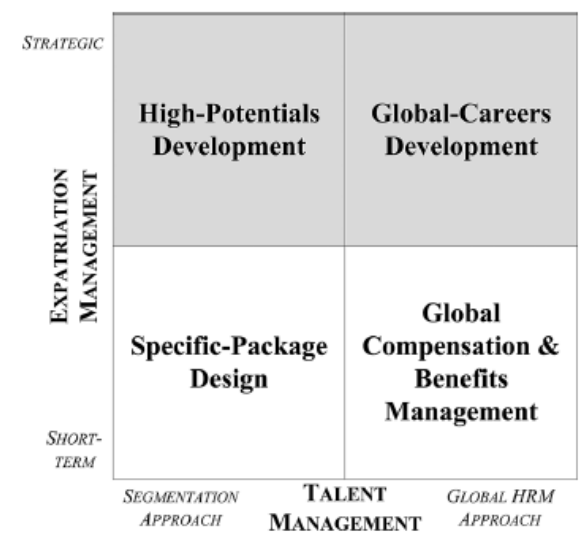

Fig. 2. Figure 1. Global Talent Management Framework.Sourrce: [36]

Supporting the argument of the important of integrating expatriate management and talent management, Collings also pinpoints the important of the integration of global mobility and global talent management that can contribute to the success of the MNE [37]. Global mobility represents an important element of the global staffing system of the contemporary MNE. It can be tools as part of leadership development, succession planning, and position filling.

\section{Repatriation Policies}

International assignment is generally challenging, exiting, and full of exposure not only for expatriates but also for their family. They have to deal with a new situation that sometimes totally different with what they experienced before. As representatives of parent company, expatriates will be assigned a challenging job and targets. Therefore, the company will provide good facilities, compensation, and benefits. The compensation practices of most MNCs reward their international assignees quite well, the international assignee and family typically live quite well in the foreign location. In contrast, after they have finished their assignment and returned to their home country, their careers are often overlooked. Some expatriates are assigned a similar position with the one that they left a couple years ago. This kind of misshandling of returning expatriates means that a good deal of critical knowledge is lost to the organization [14].

Integrated career planning needs to be developed prior to their assignment, during their assignment, and when they return to their home country. Re-entry policies should be designed to minimize the problems that can arise when expatriates return to their parent company after an overseas assignment. They want to be assured that they will be given a position that is appropriate to their qualifications, and they will be concerned about their careers. Brewster and his colleagues provided examples of best practice in this area include: pre-departure career discussions, a named contact person at the home-country organization, a mentor at the host location, re-entry counselling, family repatriation programmes, employee debriefings, and succession planning.

\section{CONCLUSION}

Since the globalization now becomes a reality, a company should exploit its business opportunity by expanding its business globally. Thus, the readiness of its human resources management that suit the managing employees in different countries become more important. The effectiveness of human resource management policies and practices across national boundaries has become a key strategy to achieve a competitive advantage in the global markets. A multinational company should concern and develop its IHRM policies and practices that enable the company to win in global business.

International Human Resource Management terms referring to the instance where an organizationôs human resource management (HRM) entails managing employees in more than one nation is one of the most disciplines that grow rapidly in recent decades. It is because of the growing need of business activities that require international studies and supported by many scholars who conduct research on this field. Many researches attempt to bridge the lack of integration between the theory and practices.

There are three main issues in IHRM field that should become the concern of a company in its intention of doing business globally. First is HRM in MNCs, which focuses on the HR management in international companies. The next issue is Cross-cultural management (CCM), which deals with the impact of cultural differences on management practices. The last issue is about comparative human resource management, which compares HRM systems and practices at both organizational and national level.

Company should implement and maintain global best practices on its human resources function. In recruiting global employees, there is a need to balance between local nationals and expatriates. The internet and social networking as one of sourcing strategies is wiedely used, providing effective and eficient sourcing methods. In the training and development, the integration of talent management and expatriate management in global career development will have significant and useful implications. Global mindset is a key aspect that should be developed in the global leader development program. Integrated career planning will be required to minimize the problems that can arise when expatriates return to their parent company after an overseas assignment.

\section{References}

[1] J. Lawler, F. Walumbwa, \& B. Bai, ñNational culture and cultura effects. In M. H. Harris (Ed.), Handbook of research in international human resource management. New York: Taylor \& Francis Group, 2006.

[2] K. Monks, H. Scullion, \& J. Creaner, ñHRM in international firms: Evidence from Irelandò. Personnel Review, 30, 2001, pp. 536-553. 
[3] D. R. Briscoe, R. S. Schuler, and L. Claus, International Human Resource Management: Policies and practices for multinational enterprises: Policy and Practice for Multinational Enterprises (Global HRM), New York: Routledge, 2000.

[4] C. A. Bartlett,\& S. Ghoshal, Managing Across Borders, Boston: Harvard Business Press, 2002.

[5] D. R. Briscoe, R.S. Schuler, \& I. Tarique, International human resource management : Policies and practices for multinational enterprises (4th ed.). London: Routledge, 2012.

[6] A.W. Harzing and J. Van Ruysseveldt, International Human Resource Management, London: SAGE Publications Ltd., 2004.

[7] R. Schuler, \& S.E. Jackson, Linking competitive strategies with human resource management practices. The Academy of Management Executive, 1(3), 1987, pp.207-219.

[8] J. L. Cheng, , \& D. Cooper, ñA strategic context approach to international human resource management research: Towards greater integration of theory and practiceò In A. M. Rugman (Ed.), Leadership in International Business Education and Research (Research in Global Strategic Management) (Emerald Group Publishing Limited ed., Vol. 8): Emerald Group Publishing Limited, 2003.

[9] M. Ozbilgin, ñInternational human resource managementò. Personnel Review, 33(2), 2004, pp. 205-221.

[10] M. Keating, \& K. Thompson, ñInternational human resource management: overcoming disciplinary sectarianismò. Employee Relations, 26(6), 2004, pp. 595-612.

[11] H.-Y. Ngo, D. Turban, C. -M. Law, \& S.-Y. Lui, òHuman practices and firm performance of multinational corporations: influence of country of originò. International Journal of Human Resource Management, 9(6), 1998, pp. 632-652.

[12] M. Armstrong, A handbook of human resource management practice (10th ed.). London: Kogan Page, 2006.

[13] R. Schuler,P. Dowling, \& H. De Cieri, ñAn integrative framework of strategic international human resource managementò. Journal of Management, 19(2), 1993, pp. 419-459.

[14] C. Brewster, P. Sparrow, G. Vernon, \& E. Houldsworth, International human resource management (3rd ed.). London: Chartered Institute of Personnel and Development, 2011.

[15] M. Dickmann, C. Brewster, \& P. Sparrow, P. International human resource management : a European perspective (2nd ed.). London ; New York: Routledge, 2008.

[16] M. Morley, and D. Collings, ñContemporary Debates and New Directions in HRM in MNCsò, International Journal of Manpower, Vol. 25, No. 6, 2004, pp. 487-559.

[17] Y. Doz, C. Bartlett, and C.K. Prahalad, "Global Competitive Pressures vs. Host Country Demands: Managing Tensions in Multinational Corporations," California Management Review 23 (3), 1981, pp. 63-74

[18] Y. Doz \& C.K. Prahalad, "Controlled Variety: A Challenge for Human Resource Management in the MNC", Human Resource Management, 25, 1, 1986, pp. 55-71.

[19] C. A. Bartlett,\& S. Ghoshal, Managing Across Borders: The transnational Solutions, Boston: Harvard Business Press, 1989.

[20] W. Grossman, \& L.F. Schoenfeldt, L. F. ñResolving ethical dilemmas through international human resource management: a transaction cost economics perspectiveò. Human Resource Management Review, 11, 2001, pp.55-72.
[21] C. Chung, O. Bozkurt, \& P. Sparrow, ñManaging the duality of IHRM unraveling the strategy and perceptions of key actors in South Korean MNCsò. The International of Human Resource Management, 23(11), 2012, pp. 2333-2353

[22] S Vanhala, $\mathrm{T}$ Kaarelson, \& $\mathrm{R}$ Alas, Converging human resource management: A comparison between Estonian and Finnish HRM, Baltic Journal of Management 1 (1), 2006, pp.82-101

[23] R. R. Sparrow, C. Brewster, and H. Harris, Globalizing Human Resource Management, London and New York : Routledge. 2004. ISBN: 0415305535.

[24] M.L. Lengnick-Hall, \& C.A. Lengnick-Hall, ñInternational human resource management and social network/social capital theoryò. In G. K. Stahl \& I. Bjo IRthan (Eds.), Handbook of Research in International Human Resource Management (pp. 475-487). Cheltenham: Edward Elgar, 2006.

[25] I. Bjo I̊kthan, \& J.E. Lervik, ñTransferring HR practices within multinational corporationsò. Human Resource Management Journal, 17(4), 2007, 320-335.

[26] C. Brewster, ñComparing HRM policies and practices across geographical bordersò. In G. K. Stahl \& I. Björkman (Eds.), Handbook of Research in International Human Resource Management. Cheltenham: Edward Elgar, 2006.

[27] C. Brewster, A. Tregaskis, A. Hegewisch, \& L. Mayne, ñComparative research in HRM: a review and exampleò. International Journal of Human Resource Management, 7(3), 1996, pp.585-604.

[28] M.M. Touron, From an ethnocentric to a geocentric approach to IHRM: The case of a French multinational company, Cross Cultural Management: An International Journal, Vol. 15 Iss: 4, 2008, pp.335 352

[29] T.D. Clarck, Ebster-Grosz, \& G. Mallory,From a universalist to a polycentric approach in organizational research Advancement in Organizational Behavior: Essays in Honor of Derek S. Pugh. Brookfield: Ashgate, 1997.

[30] J. M. Hiltrop, \& P. Sparrow, European casebook on human resource and change management. London: Prentice Hall, 1995.

[31] K. Dewettinck, \& J. Remue, ñContextualizing HRM in comparative research: The role of the Cranet networkò. Human Resource Management Review, 21(2011), pp. 37-49.

[32] V. Sinha, \& P. Thaly, ñA review on changing trend of recruitment practice to enhance the quality of hiring in global organizationsò. Management, 18(2), 2013, pp. 141-156.

[33] G. Withiam, ñBrave new world: Online hotel distributionò [Electronic article]. Cornell Hospitality Roundtable Proceedings, 3(4), 2011, pp. 614.

[34] M. Javidan, \& J.L. Walker, Developing your global mindset: The handbook for successful global leaders. Minnesota: Beaverôs Bond Press, 2013.

[35] J.-L. Cerdin, \& C. Brewster, ñTalent management and expatriation: Bridging two streams of research and practiceò. Journal of World Business, 49, 2014, pp. 245-252.

[36] D.G. Collings, ñIntegrating global mobility and global talent management: Exploring the challenges and strategic opportunitiesò. Journal of World Business, 49, 2014, pp. 253-261. 